'BELCHER, M. 1980. Birds of Regina, revised edition. Saskatchewan Nat. Hist. Soc. Spec. Publ. 12, Regina, Sask.

${ }^{2}$ CALLIN, E. M. Birds of the Qu'Appelle, 1857-1979. Saskatchewan Nat. Hist. Soc. Spec. Publ. 13, Regina, Sask.

\section{BIRD NOTES FROM SPRING VALLEY}

FLOSSIE BOGDAN, Box 92, spring Valley, Saskatchewan. SOH 3XO

Townsend's Warbler -12 miles S.E. of Spring Valley

On 5 September 1981 an overcast day, with light rain and drizzle with the sun peeking through once in a while, I was in the kitchen preparing lunch when I heard what sounded like a bird hitting the living room window. I went to check and saw a bird lying beneath the window. The bird was sort of olive green with the brightest of yellows. I rushed out to get it before the cats would. It was a warbler I had never seen before - so to the books I went. I took "Birds of North America" (Robbins, Bruun, Zim and Singer) and with the bird in my hand I walked over to my son's house. Together Larry and I identified the bird as an immature Townsend's Warbler, by the dark cheek patch outlined by bright yellow and the very bright yellow throat.

I checked the "Saskatchewan check list" and "Birds of Regina" but found no mention of a Townsend's Warbler.

I placed the bird on a soft cloth in a box, about three hours later it was ready to fly, I took it to the garden and put it on a head of a sunflower, said "good-bye" and watched as it flew to the trees. It was such a pretty little thing.

That evening after the busy day of butchering chickens I had time to think and I could have kicked myself. Why didn't we take some pictures? We had the bird in hand, but too late the bird was gone.

Had it been seen in a tree it would have been more difficult to identify, unless it posed for us.

Winter Wren - 12 miles S.E. of Spring Valley

Morning of 19 September 1980, I was out on my morning walk. As I approached a stand of willow trees a surprised little bird flew up from the underbrush of a mess of twigs overgrown with grass and weeds around the willows, it perched on a bare branch and gave out soft "tisks". I observed the kird for about 15 minutes before it disappeared under brush again. It was a tiny bird, with a short stubby tail and wrenlike actions, in the bright sunlight it appeared to be a rusty brown with an orange tinge to its breast.

Checking with "Birds of North America" (Robbins, Bruun, Zim and Singer) I identified it as a Winter Wren.

It was observed again the following day by daughter Gilbertha Leibelt, and myself - it again flew up from under the willows and perched on a dry twig.

Red-headed Woodpecker - 13 miles S.E. of Spring Valley

The afternoon of 16 July 1980 my son Allan phoned to let us know that there was a Red-headed Woodpecker at their trees, they have been watching it from their patio doors. I couldn't go just then but Larry and his wife Rhiannon went. By that time the Red-headed Woodpecker was on a power pole busy pecking away at something.

25 May 1980, 5 miles N.E. of Francis, Saskatchewan, my daughter, Gilbertha, looked out of her window and was surprised to see a Red-headed Woodpecker on their lawn, a furious 
wind was raging that day so she snapped a picture of the Red-headed Woodpecker from her kitchen window.

All birds should be as easy to identify as the Red-headed Woodpecker! but then there would be no challenge and that's what makes bird watching so exciting.

\section{CHECK-LIST OF ALBERTA BIRDS}

The fourth edition (1981) of the Alberta bird check-list has recently been published. Three hundred and fifty-two species have been included on the list; an increase of 24 species over the third edition (1975). Of interest to bird enthusiasts is the inclusion of status and abundance codes for each species in the five natural regions: grasslands, parkland, foothills, boreal forest, and Rocky Mountains. All of this information, plus a map of Alberta showing the natural regions, is reproduced in a pocket-sized foldout measuring approximately 4" x 8".

The increase in the number of provincial species over previous check-lists largely reflects the inclusion of a host of accidently occurring species. The 24 new species are: Yellow-billed Loon, Green Heron, Fulvous Whistling Duck, Garganey Teal, Black Scoter, Eskimo Curlew, Surfbird, Sharp-tailed Sandpiper, Curlew Sandpiper, Long-tailed Jaeger, Iceland Gull, Thayer's Gull, Black-legged Kittiwake, Ancient Murrelet, Chimney Swift, Vaux's Swift, Black-chinned Hummingbird, Anna's Hummingbird, Williamson's Sapsucker, Chestnut-backed Chickadee, Pygmy Nuthatch, Eastern Bluebird, Black-throated Gray Warbler, and Black-throated Sparrow.

Check-lists can be purchased (\$1.00) from the Provincial Museum of Alberta Bookshop, 12845 - 102 Avenue, Edmonton, Alberta. T5N OM6. - Dr. Philip H. R. Stepney, Curator of Ornithology, Provincial Museum of Alberta, Edmonton, Alberta. T5N 0M6.

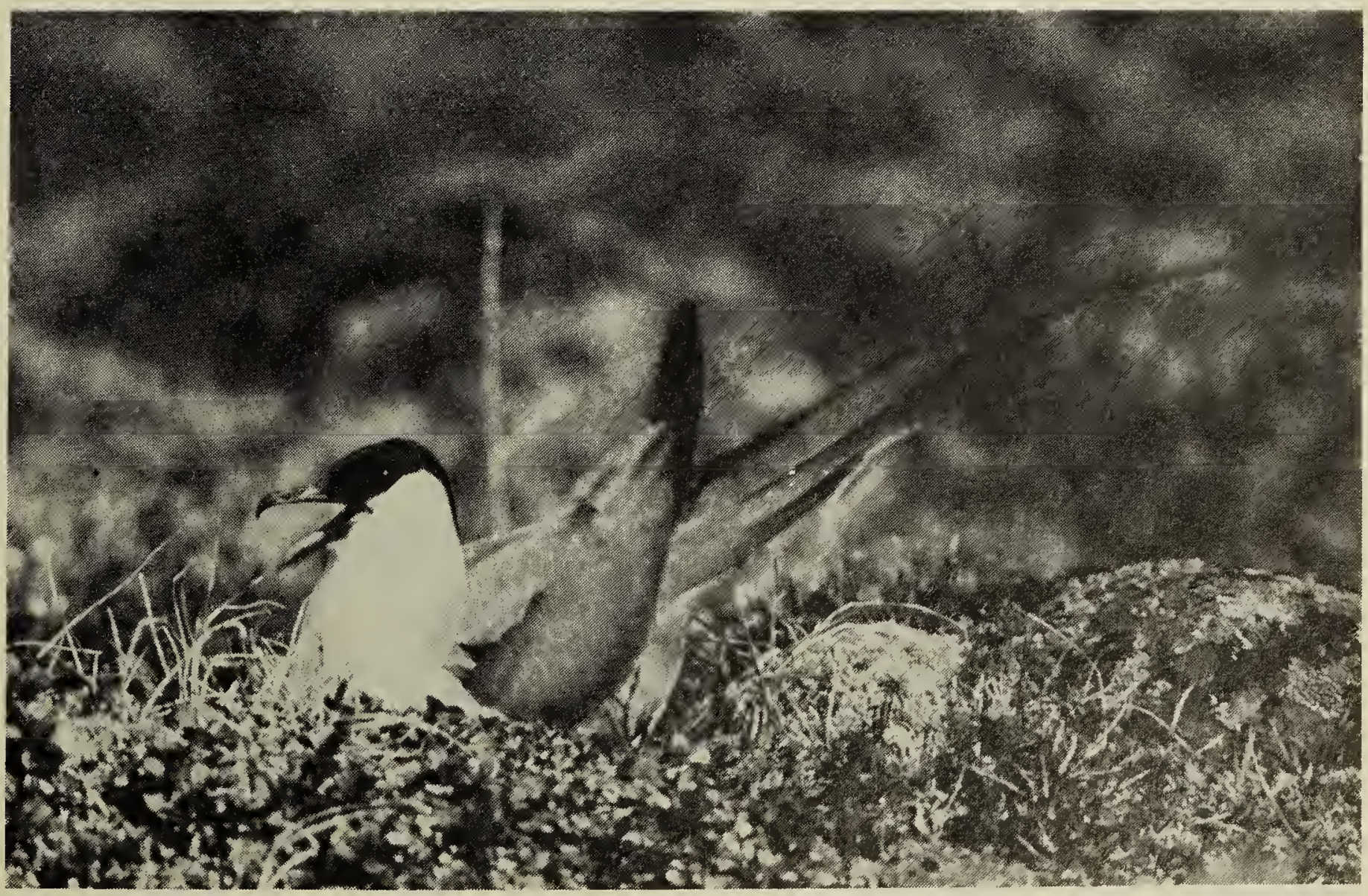

Long-tailed Jaeger, Karrak L., N.W.T.

G.W. Beyersbergen

March 1982. 40(1) 


\section{MOUNTAIN BLUEBIRD AMPUTEE}

K. MORCK, 424 - 16th St. N.W., Calgary, Alberta. T2N 2C1

The excitement of finding a bird's nest full of eggs does not lose its thrill over the years.

When it is a pair of Mountain Bluebirds, with their exquisite blue dress, that have taken possession of a recently erected bird house, and have built a nest and filled the cup with eight pale blue eggs, the thrill and excitement burst forth anew once again. Perhaps it is seeing the promise of new life to come wrapped up in a tiny egg a new hope, and the procreation of the species.

During the feeding and attending to the young in the nest box, the male bluebird unintentionally drew attention to itself by a continual but intermittent flirting of its wings when perched on a nearby branch with food in its beak for the young. The stump of one leg could sometimes be seen hanging beneath the perching branch. The foot and the lower part of the leg were missing. It had great difficulty perching, usually resting its body low over its good leg on the branch, and sometimes was seen to slide down the branch slightly, and this occasioned the flirting of the wings. It also had great difficulty entering the nest box, and made several attempts before succeeding. (Balance was poor and it could not catch a hold at the hole with the good foot and leg). It had even a greater difficulty getting out of the box after feeding the young. Its head was seen to pop up and down several times inside the hole before it finally succeeded in getting out. On occasion I opened the door and let him out. This box was in a very shaded area along a road clearance rarely used, with high grass grown up along it and with aspen poplars and low shrubbery all around at a little distance in front but close at the back of the tree on which the box had been placed.

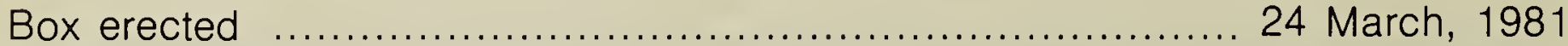

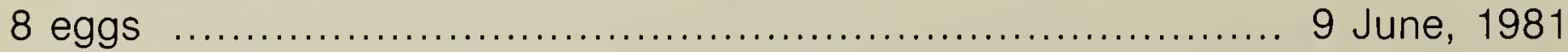

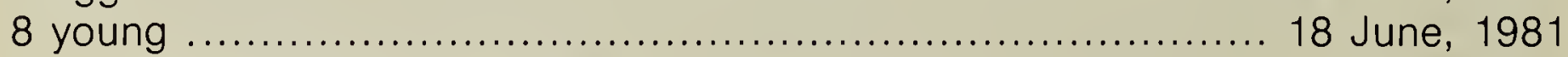
Nest vacated by last young one ............................. 2 July, 1981*

* Four feathered young found dead in the nest, mixed up with the nesting material when I cleaned it out.

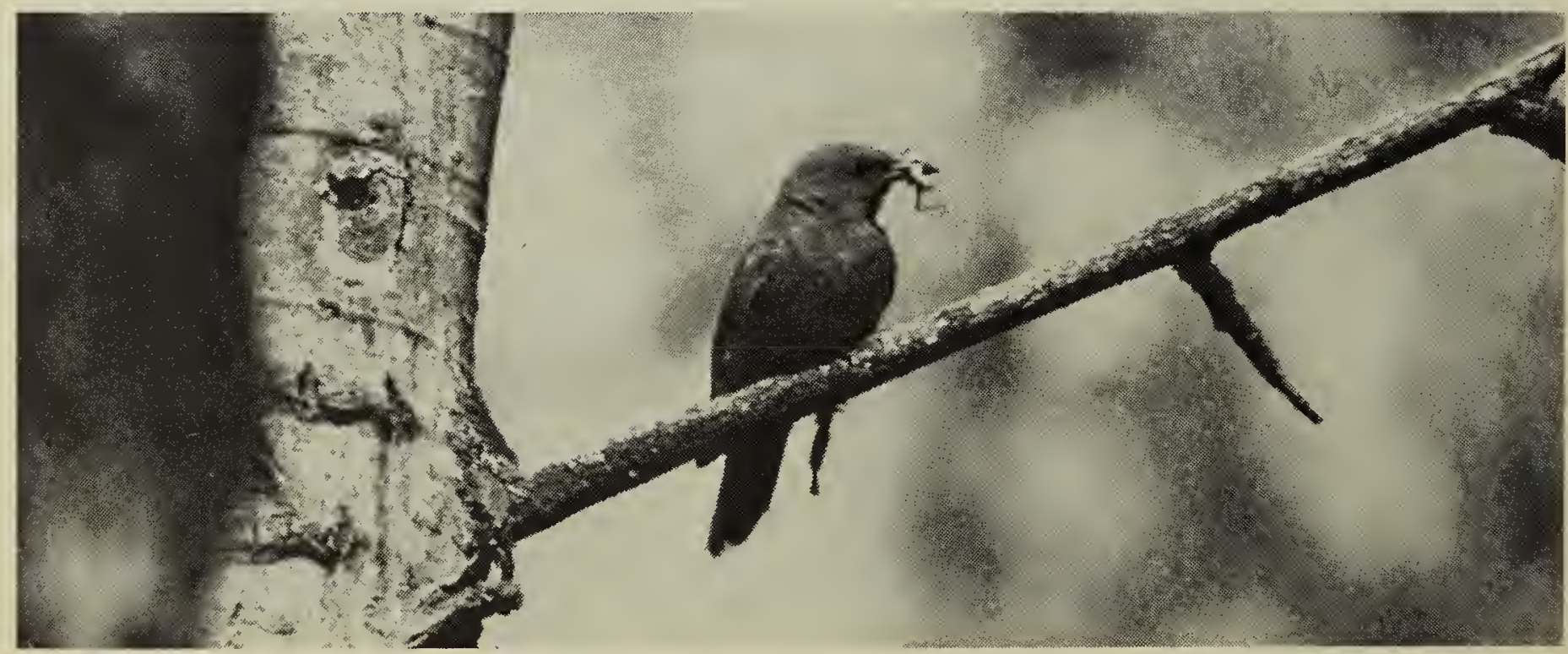

